\title{
Insect parasitoid and ant of associated on aphids (Aphididae) colonies on plants in West Java
}

\author{
Yani Maharani $^{1 *}$ Nina Maryana ${ }^{2}$, Aunu Rauf $^{2}$ \& Purnama Hidayat ${ }^{2}$ \\ ${ }^{1}$ Department of Plant Pest and Diseases, Faculty of Agriculture, Universitas Padjadjaran, Jatinangor, West Java, 45363 \\ ${ }^{2}$ Department of Plant Protection, Faculty of Agriculture, IPB University, Darmaga Campus, Bogor, West Java, 16680 \\ *Corresponding Author : yani.maharani@unpad.ac.id
}

Received November 16, 2020; revised November 18, 2020; accepted December 03, 2020

\begin{abstract}
Aphid is a sucking insect as a pest and vector of virus diseases plants. The aphids presence on plants are often accompanied by ants that symbiotic on aphid's colony. Mutualism symbiosis between ants and aphids can hinder natural enemies especially parasitoids to parasitizing aphids. This study aims to explore parasitoid and ant species associated with aphids and determine the level of parasitoid parasitization. The survey was conducted on agricultural crops and weeds in West Java area. Samples were taken by purposive sampling looking at the aphid presence, ant, and mummified colonies. Aphid's identification was carried out at Insect Biosystematics Laboratory, Department of Plant Protection IPB, whileparasitoid and ant identification was carried out at Entomology Laboratory of Zoology LIPI. The identification results obtained four species of Hymenoptera parasitoid, i.e Adialythus ambiguus, Aphidius matricariae, Praon absinthi (Braconidae) and Psyllaephagus pilossus (Encyrtidae) and eight species of ants of Formicidae family, i.e Dolichoderus sp, Dolichoderus thoracicus, Monomorium destructor, Monomorium floricola, Myrmicaria brunnea, Pheidole javana, Polyrhachis dives, and Technomyrmex albipes. The dominant parasitoid species found was A. matricariae, but the highest level of parasitization was P. pilossus (78\%), parasites Rhopalosiphum padi in rice plants. Basic information on the types of ants and parasitoid insects associated with aphids can be used in the development of aphids integrated pest management strategies.
\end{abstract}

Keywords: Hymenoptera, insect vector, mutualism, parasitization, symbiosis.

\section{ABSTRAK}

Serangga parasitoid dan semut yang berasosiasi dengan koloni kutudaun (Aphididae) diberbagai jenis tumbuhan di Jawa Barat

Kutudaun merupakan serangga penghisap cairan tanaman yang dapat menjadi hama dan vektor virus penyakit pada tanaman. Keberadaan kutudaun pada tanaman kerap disertai oleh semut yang bersimbiosis pada koloni kutudaun. Simbiosis mutualisme antara semut dengan kutudaun, dapat menghalangi musuh alami terutama parasitoid dalam memarasitisasi kutudaun. Penelitian ini bertujuan mengeksplorasi spesies semut dan parasitoid yang berasosiasi dengan kutudaun dan mengetahui tingkat parasitisasi yang terjadi. Survei dilakukan pada tanaman pertanian dan gulma di wilayah Jawa Barat. Sampel diambil secara purposive sampling dengan melihat keberadaan koloni kutudaun, semut, dan mumi kutudaun. Identifikasi kutudaun dilakukan di Laboratorium Biosistematika Serangga Departemen Proteksi Tanaman IPB. Identifikasi semut dan parasitoid dilakukan di Laboratorium Entomologi Bidang Zoologi LIPI. Hasil identifikasi parasitoid diperoleh empat spesies Hymenoptera. Keempat spesies parasitoid itu ialah Adialythus ambiguus, Aphidius matricariae, Praon absinthi (Braconidae) dan Psyllaephagus pilossus (Encyrtidae). Hasil identifikasi semut ditemukan delapan spesies dari famili Formicidae, kedelapan spesies semut tersebut ialah Dolichoderus sp, Dolichoderus thoracicus, Monomorium destructor, Monomorium floricola, Myrmicaria brunnea, Pheidole javana, Polyrhachis dives, dan Technomyrmex albipes. Spesies parasitoid yang dominan ditemukan ialah A. matricariae. Tingkat parasitisasi parasitoid tertinggi mencapai $78 \%$ oleh spesies $P$. pilossus pada kutudaun Rhopalosiphum padi yang hidup di tanaman padi. Informasi dasar tentang jenis semut dan serangga parasitoid yang berasosiasi dengan kutudaun dapat dimanfaatkan dalam pengembangan strategi pengendaian hama terpadu kutudaun.

Kata Kunci: Hymenoptera, mutualisme, parasitisasi, serangga vektor, simbiosis.

\section{PENDAHULUAN}

Mengetahui keanekaragaman musuh alami seperti predator dan parasitoid untuk dijadikan sebagai pengendalian hayati kutudaun sangat penting. Populasi musuh alami di lapangan sangat tergantung pada populasi inang dan lingkungan yang mendukungnya. Lingkungan yang dimaksud ialah tersedianya tumbuhan berbunga sebagai sumber pakan bagi imago dan iklim yang mendukung perkembangannya. Parasitoid yang efektif mampu mengendalikan populasi inangnya. Hubungan kepadatan inang dengan persentase parasitisasi merupakan hal penting dalam interaksi inang parasitoid. Sebagian besar parasitoid kutudaun mampu memarasit beberapa spesies kutudaun, tetapi kemudian diketahui bahwa sepertiga dari jumlah parasitoid yang ada hanya memarasit spesies tertentu (spesifik inang). Perubahan sifat tersebut dapat terjadi akibat penggunaan pestisida, karena imago parasitoid rentan terhadap pestisida sehingga preferensi 
parasitoid terhadap inangnya dapat berubah (Kos et al., 2008). Kemampuan parasitoid mencari dan menemukan inangnya sangat dipengaruhi oleh chemoreseptor (indera penciuman) yang dimilikinya. Metabolit sekunder yang terkandung di dalam tubuh inang (kutudaun) dapat mempengaruhi parasitoid dalam memarasitisasi inangnya (Schoonhoven et al., 2005). Selain metabolit sekunder yang dihasilkan inang, morfologi inang seperti ukuran tubuh, warna, dan bentuk permukaan tubuh juga mempengaruhi parasitoid dalam memarasitisasi inangnya. Struktur permukaan tumbuhan inang juga berpengaruh terhadap aktivitas parasitoid dalam mencari inangnya (Volkl \& Stechmann, 1998).

Keberhasilan parasitoid dalam menemukan serangga inangnya juga dipengaruhi oleh senyawa volatile yang dihasilkan oleh tumbuhan tempat kutudaun membentuk koloni. Senyawa volatile yang dihasilkan terbawa angin akan mengarahkan parasitoid menemukan koloni kutudaun. Keberhasilan parasitoid dalam menemukan koloni kutudaun yang dipandu oleh senyawa volatile dipengaruhi oleh arah dan kecepatan angin (Kitt \& Keller, 1998).

Keefektifan parasitoid dalam mengendalikan populasi inang dapat diukur dari daya parasitisasinya. Berdasarkan daya parasitisasinya tersebut dapat dinilai kemampuan parasitoid dalam mengatur keseimbangan populasi inang. Parasitoid yang efektif dicirikan dengan; (1) kemampuan mencari inang yang tinggi, terutama pada saat populasi inang rendah (kemampuan mencari ini ditentukan tanggap fungsional dari parasitoid tersebut, (2) kekhususan terhadap inang, (3) potensi reproduksinya tinggi (dicirikan oleh keperidian dan fertilitas yang tinggi serta siklus hidup yang pendek), (4) kisaran toleransi terhadap lingkungan lebar serta kemampuan memarasitisasi berbagai stadia instar inang (De Bach 1974).

Parasitoid kutudaun sebagian besar tergolong ke dalam Ordo Hymenoptera. Parasitoid kutudaun yang telah diketahui tergolong ke dalam empat famili, yaitu famili Aphidiidae, Aphelinidae, Encyrtidae, dan Mymaridae (Hagen \& van den Bosch 1968). Spesies dari Famili Aphidiidae dan Aphelinidae merupakan parasitoid yang paling banyak ditemukan pada mumi kutudaun. Telah dilaporkan sekitar 17 spesies dan 8 genus parasitoid dari famili Aphidiidae mampu memarasit kutudaun (Kos et al., 2008).

Spesies Aphidius matricariae (Haliday) dan Lysiphlebus fabarum (Marshall) memiliki tingkat parasitisasi yang paling tinggi terhadap kutudaun dan sebagian besar keturunan yang dihasilkan adalah betina. Ditemukan 24 spesies Aphidiinae dan 3 spesies Aphelinidae yang merupakan parasitoid primer kutudaun (Westrum et al., 2010). Ada enam spesies parasitoid yang memarasit Myzus spersicae di Jawa Barat, yaitu Aphidius rosae Haliday, Aphidiusdelicates Baker, Aphidius sp., Diaeretiella rapae (M'intosh) (Aphidiidae), Aphelinus asychis
(Walker), dan Aphelinus sp. (Aphelinidae) (Irsan, 2004).

Keberhasilan parasitoid dalam memarasit kutudaun tidak lepas dari keberadaan semut. Simbiosis mutualisme antara kutudaun dan semut dapat terjadi karena kutudaun menghasilkan ekskresi embun madu yang kaya asam amino dan menjadi sumber pakan bagi semut. Koloni kutudaun memanfaatkan keberadaan semut sebagai pelindung atau pertahanan terhadap serangan parasitoid maupun predator. Keberadaan semut pada koloni kutudaun kerap kali menghalangi proses parasitisasi yang dilakukan parasitoid, sehingga populasi kutudaun dapat berkembang dengan cepat. Penelitian ini bertujuan untuk mengkaji spesies parasitoid yang berperan di alam dalam mengatur pertumbuhan populasi kutudaun, tingkat parasitisasi dan sebarannya, serta jenis semut yang berasosiasi dengan koloni kutudaun.

\section{BAHAN DAN METODE}

Penelitian dilakukan dengan metode survei dan pengambilan sampel dilakukan bersamaan dengan pengambilan sampel kutudaun. Setiap lokasi mewakili topografi Jawa Barat yang terdiri dari dataran rendah $<200 \mathrm{~m}$ dari permukaan laut (dpl), dataran sedang 200-700 m dpl, dan dataran tinggi >700 m dpl. Sampel diambil dari koloni kutudaun yang berada diberbagai jenis tanaman pertanian dan gulma disekitarnya. Pengambilan sampel meliputi daerah Bogor, Sukabumi, Cianjur, Karawang, Subang, Lembang, Pangalengan, Ciamis, Garut, Tasikmalaya, Cirebon, dan Kuningan.

\section{Koleksi Parasitoid dan Semut di Lapangan}

Pengambilan sampel parasitoid dan semut dilakukan pada koloni kutudaun yang ditemukan pada setiap tanaman inang di berbagai ketinggian tempat. Posisi geografi dan ketinggian tempat pengambilan sampel diukur dengan menggunakan aplikasi GPS (Global Positioning System) dari Magellan GPS 315. Sampel diambil dari koloni kutudaun yang berada diberbagai jenis tanaman yang telah ditentukan.

Teknik koleksi parasitoid yang digunakan mengacu kepada teknik pengoleksian yang dikembangkan oleh Kos et al. (2008). Kutudaun yang masih hidup dan mumi kutudaun diambil dan dimasukkan kedalam kotak plastik dengan menyertakan bagian tanaman inangnya. Kotak plastik yang berisi kutudaun ditutup dengan kain berbahan nilon rapat agar imago parasitoid tidak keluar dari kurungan, serta kelembaban dan sirkulasi udara tetap terjaga. Setiap wadah diberi tanda berupa label yang berisikan jumlah serangga sampel, tanggal pengambilan dan lokasi pengambilan. Semut yang ditemukan pada koloni kutudaun dimasukkan ke dalam tabung eppendorf berisi alkohol $70 \%$ kemudian diidentifikasi. Setiap parasitoid yang muncul diambil dan dimasukkan ke dalam botol eppendorf yang berisi alkohol $70 \%$ untuk identifikasi. 


\section{Identifikasi Parasitoid dan Semut}

Proses pembuatan awetan spesimen parasitoid dan semut dilakukan di Laboratorium Biosistematika Serangga, Departemen Proteksi Tanaman, IPB dan Laboratorium Entomologi LIPI. Proses pengawetan spesimen menggunakan teknik koleksi kering menggunakan karton pinning segitiga untuk mempermudah identifikasi spesies. Identifikasi parasitoid mengacu kepada beberapa buku identifikasi parasitoid dari tingkat ordo hingga tingkat genus atau spesies, seperti Shaw \&Huddleston (1991) dan Goulet \& Huber (1993). Identifikasi semut dilakukan dengan mengacu pada buku yang disusun oleh Hashimoto (2003) dan Outrop (2014).

\section{Tingkat Parasitisasi}

Tingkat parasitisasi dihitung berdasarkan jumlah mumi yang ada per koloni kutudaun atau jumlah mumi yang ada per luas bagian tanaman pada saat, populasi kutudaun yang ditemukan tinggi. Untuk mendapatkan tingkat parasitisasi digunakan rumus sebagai berikut:

Tingkat parasitisasi $(\%)=\quad$ Jumlah mumi $\times 100 \%$

\section{HASIL DAN PEMBAHASAN}

\section{Parasitoid yang Berasosiasi dengan Koloni Kutudaun \\ Hasil penelitian menunjukkan bahwa} keseluruhan parasitoid yang diperoleh dari hasil penelitian ini tergolong Ordo Hymenoptera. Ada empat spesies parasitoid yang ditemukan memarasit pada 11 spesies kutudaun di Jawa Barat (Tabel 1). Tiga jenis parasitoid yang tergolong Famili Braconidae, yaitu Aphidius matricariae Haliday, Adialythus ambiguus (Haliday), Praon absinthii Bignell, dan Famili Encyrtidae (Psyllaephagus pilossus Noyes). Keempat spesies parasitoid tersebut merupakan parasitoid primer pada kutudaun. Spesies parasitoid tersebut banyak ditemukan memarasit kutudaun Aphis gossypii Glover dan Myzus persicae (Sulzer).

Kelompok parasitoid yang dominan ditemukan dalam koloni kutudaun di Jawa Barat tergolong ke dalam Famili Braconide. Braconidae merupakan anggota dari Subfamili Aphidiinae yang bersifat soliter dan endoparasitoid pada kutudaun.

$\overline{\text { Jumlah kutudaun hidup + mumi }}$

Tabel 1. Spesies parasitoid yang ditemukan memarasitisasi kutudaun di berbagai spesies tanaman inang di Jawa Barat

\begin{tabular}{|c|c|c|c|}
\hline Spesies parasitoid & Famili & Spesies kutudaun & Tanaman inang \\
\hline \multirow[t]{6}{*}{$\begin{array}{l}\text { Aphidius matricariae } \\
\text { Haliday }\end{array}$} & \multirow[t]{6}{*}{ Braconidae } & Aphis gossypii Glover & $\begin{array}{l}\text { Cabai (Capsicum annum), Paria } \\
\text { (Momordica charantia) }\end{array}$ \\
\hline & & $\begin{array}{l}\text { Macrosiphum } \\
\text { euphorbiae (Thomas) }\end{array}$ & $\begin{array}{l}\text { Kentang (Solanum tuberosum), Terung } \\
\text { putih (Solanum melongena) }\end{array}$ \\
\hline & & $\begin{array}{l}\text { Myzus persicae } \\
\text { (Sulzer) }\end{array}$ & Cabai (Capsicum annum) \\
\hline & & $\begin{array}{l}\text { Semiaphis heraclei } \\
\text { (Takahashi) }\end{array}$ & Seledri (Apium graveolens) \\
\hline & & Aphis craccivora Koch & Trembesi (Albizia saman) \\
\hline & & $\begin{array}{l}\text { Aphis nasturtii } \\
\text { Kaltenbach }\end{array}$ & Mentimun (Cucumis sativus) \\
\hline \multirow[t]{2}{*}{$\begin{array}{l}\text { Adialythus } \\
\text { ambiguus } \\
\text { (Haliday) }\end{array}$} & \multirow[t]{2}{*}{ Braconidae } & $\begin{array}{l}\text { Lipaphis } \\
\text { pseudobrassicae } \\
\text { (Kaltenbach) }\end{array}$ & Lobak (Raphanus sativus) \\
\hline & & $\begin{array}{l}\text { Macrosiphum pallidum } \\
\text { (Oestlund) }\end{array}$ & Mawar (Rossa sp.) \\
\hline $\begin{array}{l}\text { Praon absinthii } \\
\text { Bignell }\end{array}$ & Braconidae & Aphis gossypii Glover & Terung (Solanum melongena) \\
\hline \multirow[t]{5}{*}{$\begin{array}{l}\text { Psyllaephagus } \\
\text { pilossus Noyes }\end{array}$} & \multirow[t]{5}{*}{ Encyrtidae } & $\begin{array}{l}\text { Aphis frangulae } \\
\text { Kaltenbach }\end{array}$ & Kentang (Solanum tuberosum) \\
\hline & & Aphis gossypii Glover & $\begin{array}{l}\text { Cabai (Capsicum annum), Kembang } \\
\text { sepatu (Hibiscus rossasinensis) }\end{array}$ \\
\hline & & Aphis spiraecola Patch & Kelor (Moringa oleifera) \\
\hline & & $\begin{array}{l}\text { Myzus persicae } \\
\text { (Sulzer) }\end{array}$ & Pepino (Solanum muricatum) \\
\hline & & $\begin{array}{l}\text { Rhopalosiphum padi } \\
\text { (Linnaeus) }\end{array}$ & Padi (Oryza sativa) \\
\hline
\end{tabular}

Famili Braconidae merupakan parasitoid kutudaun yang memiliki kelimpahan dan daya pencar yang tinggi serta efektif menekan perkembangan populasi kutudaun diberbagai tanaman inang pada lokasi yang berbeda-beda (Rakhshani et al., 2007; Rakhshani et al., 2008; Akhtar et al., 2011a; Akhtar et 
al., 2011b; Stary et al, 2014, Chaouche \& Laamari, 2015). Keberhasilan penggunaan Aphidiinae sebagai agens biokontrol dipengaruhi oleh pengetahuan tentang taksonomi mereka, perilaku seleksi inang, dan ekologi parasitoid tersebut (Rehman \& Powell, 2010).

Parasitoid yang paling banyak ditemukan pada koloni kutudaun ialah $A$. matricariae (Aphidiinae: Braconidae). A. matricariae memiliki kisaran inang yang sangat luas dan mampu memarasit beberapa spesies kutudaun (Akhtar et al., 2011). Parasitoid tersebut juga memiliki kemampuan memarasitisasi dan daya pencar yang tinggi di daerah India, sehingga sering digunakan sebagai musuh alami kutudaun (Dey \& Akhtar, 2007). Selain Braconidae, Famili Encyrtidae termasuk parasitoid yang berpotensi mengendalikan populasi Hemipteran yang bertubuh lunak seperti kutuputih dan kelompok kutu lainnya di tanaman pertanian. Spesies Encyrtidae juga memiliki kespesifikan inang dan dapat menekan perkembangan populasi kutudaun (Manickavasagam \& Rameshkumar, 2012). Encyrtidae adalah famili yang jumlah spesies paling banyak pada Superfamili Chalcidoidea, sehingga keberadaan spesiesnya sering ditemukan di lapangan (Noyes, 2004).

\section{Tingkat parasitisasi pada koloni kutudaun}

Rata-rata tingkat parasitisasi pada keempat jenis parasitoid yang ditemukan tidak terlalu tinggi. Parasitoid yang memiliki tingkat parasitisasi tertinggi ialah A.matricariae (36.57\%), tingkat parasitisasi parasitoid lainnya ialah $P$. pilossus $(33.16 \%), A$. ambiguus (32.5\%), dan P. Absinthia (22\%) (Tabel 2). Spesies kutudaun yang paling banyak ditemukan terparasit ialah $A$. gossypii dan $M$. persicae. Kedua spesies kutudaun tersebut bersifat polifag, sehingga keberadaannya sering ditemukan di lapangan.

Tabel 2. Tingkat parasitisasi beberapa spesies parasitoid yang memarasitisasi kutudaun di Jawa Barat

\begin{tabular}{|c|c|c|c|c|}
\hline Spesies parasitoid & Spesies kutudaun & $\begin{array}{c}\text { Populasi } \\
\text { inang (ekor/ } \\
\text { kelompok) }\end{array}$ & $\begin{array}{c}\text { Jumlah mumi } \\
\text { (ekor/ } \\
\text { kelompok) }\end{array}$ & $\begin{array}{c}\text { Tingkat } \\
\text { parasitisasi } \\
(\%)\end{array}$ \\
\hline \multirow[t]{2}{*}{$\begin{array}{l}\text { Adialythus ambiguus } \\
\text { (Haliday) }\end{array}$} & $\begin{array}{l}\text { Lipaphis pseudobrassicae } \\
\text { (Kaltenbach) }\end{array}$ & 4 & 1 & 25 \\
\hline & $\begin{array}{l}\text { Macrosiphum pallidum } \\
\text { (Oestlund) }\end{array}$ & 5 & 2 & 40 \\
\hline \multirow{7}{*}{$\begin{array}{l}\text { Aphidius matricariae } \\
\text { Haliday }\end{array}$} & Aphis gossypii Glover & 12 & 2 & 16 \\
\hline & & 5 & 1 & 20 \\
\hline & $\begin{array}{l}\text { Macrosiphum euphorbiae } \\
\text { (Thomas) }\end{array}$ & 4 & 2 & 50 \\
\hline & Myzus persicae (Sulzer) & 6 & 2 & 33 \\
\hline & Semiaphis heraclei (Takahashi) & 3 & 1 & 33 \\
\hline & Aphis craccivora Koch & 7 & 5 & 71 \\
\hline & Aphis nasturtii Kaltenbach & 3 & 1 & 33 \\
\hline Praon absinthii Bignell & Aphis gossypii Glover & 9 & 2 & 22 \\
\hline \multirow{6}{*}{$\begin{array}{l}\text { Psyllaephagus pilossus } \\
\text { Noyes }\end{array}$} & Aphis frangulae Kaltenbach & 7 & 1 & 14 \\
\hline & Aphis gossypii Glover & 3 & 1 & 33 \\
\hline & & 3 & 1 & 33 \\
\hline & Aphis spiraecola Patch & 12 & 2 & 16 \\
\hline & Myzus persicae (Sulzer) & 4 & 1 & 25 \\
\hline & Rhopalosiphum padi (Linnaeus) & 14 & 11 & 78 \\
\hline
\end{tabular}

Secara umum tingkat parasitisasi yang terjadi pada koloni kutudaun di Jawa Barat tidak terlalu tinggi. Hal itu dapat dilihat dari jumlah mumi kutudaun yang ditemukan. Proses parasitisasi parasitoid dipengaruhi oleh berbagai faktor, di antaranya faktor fisik dan kimia tanaman inang, ukuran dan kebugaran kutudaun sebagai inang, suhu, dan keberadaan musuh alami lainnya yang ada di lokasi inang (Powell et al., 1998). Parasitoid merespon rangsangan semiokimia dan fisik untuk menemukan dan mengenali inangnya. Respons itu disebabkan oleh feromon seks kutudaun yang berperan sebagai kairomon atau volatile tanaman inang kutudaun, yang bereran sebagai sinomon.
Secara umum mumi kutudaun yang ditemukan berada pada fase imago, hal tersebut dapat menyebabkan rendahnya tingkat parasitisasi. Sifat parasitoid kutudaun lebih menyukai inang pada fase nimfa dibandingkan dengan fase imago. Aphidius ervi Haliday parasitoid Aulacorthum solani menyukai inang pada fase nimfa (5 hari setelah nimfa diletakkan) (Rocca \& Messelink, 2016) dan tingkat parasitisasi akan tinggi jika pada koloni tersebut tidak terdapat musuh alami lainnya seperti predator (Acheampong et al. 2012). Menurut Gontijo et al. (2015) kemampuan memarasitisasi Aphelinus mali akan meningkat apabila pada patch tersebut tidak terdapat predator primer seperti cocopet, lalat syrpid, kumbang predator dan laba-laba. Keberhasilan 
parasitoid dalam memarasitisasi inangnya juga dipengaruhi oleh keberadaan serangga lain yang bersimbiosis di wilayah tersebut. Menurut (Messelink et al., 2011; Roubinet et al., 2015) keterlibatan beberapa spesies musuh alami dalam suatu wilayah baik berinteraksi secara langsung maupun tidak langsung antar spesies akan mempengaruhi keberhasilan pengendalian secara biologi.

Kutudaun yang bugar akan menjadi daya tarik bagi parasitoid. Proses parasitoid dalam mencari dan menemukan inangnya sangat dipengaruhi oleh reseptor kimiawi. Metabolit sekunder yang terkandung di dalam tubuh inang (kutudaun) dapat mempengaruhi parasitoid dalam memarasitisasi inangnya (Schoonhoven et al., 2005). Selain metabolit sekunder yang dihasilkan inang, morfologi inang seperti ukuran tubuh, warna, dan bentuk permukaan tubuh juga mempengaruhi parasitoid dalam memarasit inangnya. Struktur permukaan tumbuhan inang juga berpengaruh terhadap aktivitas parasitoid dalam mencari inangnya (Volkl \& Stechmann, 1998). Mutualisme yang terjadi antara semut dengan kutudaun secara tidak langsung akan mempengaruhi kemampuan parasitoid dalam memarasitisasi inangnya. Pada saat penelitian ditemukan spesies semut $D$. thoracicus yang berasosiasi pada koloni kutudaun. Diduga keberadaan semut pada koloni kutudaun tersebut dapat mengurangi keberhasilan parasitoid parasitisasi kutudaun

\section{Sebaran Parasitoid Kutudaun di Jawa Barat}

Berdasarkan hasil survei, spesies parasitoid hanya ditemukan pada ketinggian diatas $200 \mathrm{~m} \mathrm{dpl}$. Dataran tinggi (>700 m dpl) merupakan daerah yang paling banyak parasitoid ditemukan, yaitu empat spesies. Dataran sedang (200-700 m dpl) ditemukan 3 spesies parasitoid dan pada dataran rendah $(0-200 \mathrm{~m}$ dpl) parasitoid tidak ditemukan (Tabel 3).

Tabel 3. Sebaran parasitoid yang ditemukan memarasitisasi kutudaun di beberapa lokasi penelitian di Jawa Barat

\begin{tabular}{|c|c|c|}
\hline Kategori ketinggian & Lokasi dan elevasi & Spesies parasitoid \\
\hline $\begin{array}{l}\text { Dataran rendah }<200 \mathrm{~m} \\
\mathrm{dpl}\end{array}$ & - & - \\
\hline \multirow[t]{5}{*}{$\begin{array}{l}\text { Dataran sedang 200- } \\
700 \mathrm{~m} \mathrm{dpl}\end{array}$} & Bogor $\left(106^{\circ} 43^{\prime} 45.69^{\prime \prime E} ; 6^{\circ} 35^{\prime} 40.66^{\prime \prime S} / 227 \mathrm{~m} \mathrm{dpl}\right)$ & $\begin{array}{l}\text { Aphidius matricariae } \\
\text { Haliday }\end{array}$ \\
\hline & Bogor (10644'44.13"E;6³4'10.79"S/ 190 m dpl) & \\
\hline & Bogor $\left(106^{\circ} 49^{\prime} 0.64^{\prime \prime} \mathrm{E} ; 6^{\circ} 36^{\prime} 3.98^{\prime \prime} \mathrm{S} / 266 \mathrm{~m} \mathrm{dpl}\right)$ & \\
\hline & $\begin{array}{l}\text { Tasikmalaya }\left(102^{\circ} 13^{\prime} 5.20^{\prime \prime} \mathrm{E} ; 7^{\circ} 19^{\prime} 35.63 ’ \mathrm{~S} / 354 \mathrm{~m}\right. \\
\mathrm{dpl})\end{array}$ & $\begin{array}{l}\text { Adialythus ambiguus } \\
\text { (Haliday) }\end{array}$ \\
\hline & $\begin{array}{l}\text { Tasikmalaya }\left(102^{\circ} 11^{\prime} 3.39^{\prime \prime E} ; 7^{\circ} 20^{\prime} 34.13 " \mathrm{~S} / 388 \mathrm{~m}\right. \\
\mathrm{dpl})\end{array}$ & $\begin{array}{l}\text { Psyllaephagus pilossus } \\
\text { Noyes }\end{array}$ \\
\hline \multirow[t]{13}{*}{$\begin{array}{l}\text { Dataran tinggi }>700 \mathrm{~m} \\
\mathrm{dpl}\end{array}$} & Bogor (10657'12.77"E;6³8'54.80"S/ 1153 m dpl) & $\begin{array}{l}\text { Adialythus ambiguus } \\
\text { (Haliday) }\end{array}$ \\
\hline & Garut (10745’44.63’'E;7¹2’13.01’S/1431 m dpl) & $\begin{array}{l}\text { Aphidius matricariae } \\
\text { Haliday }\end{array}$ \\
\hline & $\begin{array}{l}\text { Lembang }\left(107^{\circ} 39^{\prime} 25.30^{\prime \prime} \mathrm{E} ; 6^{\circ} 48^{\prime} 47.72^{\prime \prime S} / 1170 \mathrm{~m}\right. \\
\text { dpl) }\end{array}$ & \\
\hline & $\begin{array}{l}\text { Lembang (107³9’25.30”E;648’47.72”S/ } 1170 \text { m } \\
\text { dpl) }\end{array}$ & \\
\hline & Garut $\left(107^{\circ} 45^{\prime} 44.63 ” \mathrm{E} ; 7^{\circ} 12^{\prime} 13.01{ }^{\prime} \mathrm{S} / 1431 \mathrm{~m} \mathrm{dpl}\right)$ & \\
\hline & Bogor $\left(6^{\circ} 39^{\prime} 24.45^{\prime \prime S} 106^{\circ} 41^{\prime} 51.01 " \mathrm{E} / 633 \mathrm{~m} \mathrm{dpl}\right)$ & \\
\hline & $\begin{array}{l}\text { Lembang (107³7’2.08’E; 649’25.00’S/ } 1185 \mathrm{~m} \\
\text { dpl) }\end{array}$ & Praon absinthii Bignell \\
\hline & $\begin{array}{l}\text { Pangalengan (107³3’3.39’'E;7¹1'52.83”S/ } 1438 \\
\text { m dpl) }\end{array}$ & $\begin{array}{l}\text { Psyllaephagus pilossus } \\
\text { Noyes }\end{array}$ \\
\hline & Cianjur $\left(6^{\circ} 46.00 " \mathrm{~S} ; 107^{\circ} 02.57^{\prime \prime E} / 1020 \mathrm{~m} \mathrm{dpl}\right)$ & \\
\hline & Cianjur $\left(6^{\circ} 74^{\prime} 86.4^{\prime \prime S} ; 107^{\circ} 05^{\prime} 92.9^{\prime \prime E} / 1157 \mathrm{~m} \mathrm{dpl}\right.$; & \\
\hline & $\left.107^{\circ} 0^{\prime} 32.93 " \mathrm{E} ; 6^{\circ} 44^{\prime} 1.30^{\prime \prime S} / 1295 \mathrm{~m} \mathrm{dpl}\right)$ & \\
\hline & $\begin{array}{l}\text { Sukabumi (10654'17. 21’E;649'7.27’S/ } 1029 \mathrm{~m} \\
\text { dpl) }\end{array}$ & \\
\hline & $\begin{array}{l}\text { Lembang (107³9’25.30”E;648’47.72”S/ } 1170 \text { m } \\
\text { dpl) }\end{array}$ & \\
\hline
\end{tabular}

Parasitoid kutudaun memiliki habitat yang bervariasi dan preferensi yang mempengaruhi asosiasi dan daya jelajah dalam menemukan inang. Sifat ekologi dan perilaku trofik setiap parasitoid akan mempengaruhi distribusi geografis dan fenologinya
(Starý \& Havelka, 2008). Faktor iklim dan suhu merupakan faktor penting bagi kehidupan tanaman dan serangga. Perubahan musim dalam jangka panjang akan mempengaruhi dinamika populasi serangga. Parameter abiotik memiliki dampak 
langsung terhadap perkembangan, kelangsungan hidup, fekunditas, voltinisme dan penyebaran serangga (Karuppaiah \&Sujayanad, 2012).

Sebaran tanaman inang kutudaun dapat mempengaruhi sebaran parasitoidnya. Beberapa tanaman inang kutudaun memiliki karakter khusus yang hanya mampu tumbuh pada kondisi tertentu, seperti tanaman Cruciferae yang tumbuh baik di dataran sedang dan tinggi dengan kelembapan yang tinggi. Hal tersebut akan mempengaruhi jenis kutudaun yang berkembang, dan spesies parasitoid yang berasosiasi. Parasitoid Aphidiinae seperti $A$. matricariae, memiliki daya adaptasi dan jelajah yang tinggi sampai ke daerah pegunungan, parasitoid tersebut memiliki keragaman yang tinggi (Stary et al., 2014). Suhu dan iklim yang cocok membuat tumbuhan menjadi subur sehingga nutrisi yang dibutuhkan oleh serangga herbivora terpenuhi. Hal itulah yang menjadi daya tarik bagi kutudaun maupun parasitoidnya.

\section{Semut yang Berasosiasi dengan Koloni Kutudaun}

Ada delapan spesies semut yang tergolong famili Formicidae ditemukan berasosiasi dengan koloni 21 spesies kutudaun (Tabel 4). Delapan spesies semut yang ditemukan itu ialah Dolichoderus thoracicus, Dolichoderus sp., Monomorium floricola, Monomorium destructor, Myrmicaria brunnea, Pheidole javana, Polyrhachis dives, dan Technomyrmex albipes. Spesies D. thoracicus merupakan spesies semut yang paling sering ditemukan berasosiasi dengan koloni kutudaun.

Tabel 4. Spesies semut yang ditemukan berasosiasi dengan koloni kutudaun di beberapa spesies tanaman inang di Jawa Barat.

\begin{tabular}{|c|c|c|c|c|}
\hline Spesies semut & Subfamili & Famili & Spesies kutudaun & Tanaman inang \\
\hline \multirow[t]{20}{*}{$\begin{array}{l}\text { Dolichoderus } \\
\text { thoracicus }\end{array}$} & Dolichoderinae & Formicidae & Aphis craccivora Koch & $\begin{array}{l}\text { Kenikir (Cosmos } \\
\text { kaudatus), kacang panjang } \\
\text { (Vigna sinensis) }\end{array}$ \\
\hline & & & Aphis eugeniae van der Goot & $\begin{array}{l}\text { Katuk (Sauropus } \\
\text { androgynus) }\end{array}$ \\
\hline & & & Aphis fabae Scopoli & $\begin{array}{l}\text { Anggrek tanah } \\
\text { (Epidendrum ibaguense), } \\
\text { jagung (Zea mays) }\end{array}$ \\
\hline & & & Aphis gossypii Glover & $\begin{array}{l}\text { Cabai (Capsicum annum), } \\
\text { Kembang sepatu } \\
\text { (Hibiscus rossasinensis) }\end{array}$ \\
\hline & & & Aphis nasturtii Kaltenbach & Cabai (Capsicum annum). \\
\hline & & & Aphis spiraecola Patch & Asoka (Saraca indica) \\
\hline & & & $\begin{array}{l}\text { Astegopteryx nipae (van der } \\
\text { Goot) }\end{array}$ & Kelapa (Cocos nucifera) \\
\hline & & & $\begin{array}{l}\text { Astegopteryx pallida (van der } \\
\text { Goot) }\end{array}$ & Bambu (Bambusa sp.). \\
\hline & & & $\begin{array}{l}\text { Aulacorthum solani } \\
\text { (Kaltenbach) }\end{array}$ & $\begin{array}{l}\text { Bunga tasbih (Canna } \\
\text { indica) }\end{array}$ \\
\hline & & & $\begin{array}{l}\text { Cerataphi sbrasiliensis } \\
\text { (Hempel) }\end{array}$ & $\begin{array}{l}\text { Palem kuning } \\
\text { (Chrysalidocarpus } \\
\text { lutescens), kelapa (Coccos } \\
\text { nucifera). }\end{array}$ \\
\hline & & & $\begin{array}{l}\text { Ceratoglyphina bambusae } \\
\text { (van der Goot) }\end{array}$ & $\begin{array}{l}\text { Bambu kuning (Bambusa } \\
\text { sp.) }\end{array}$ \\
\hline & & & $\begin{array}{l}\text { Greenideoida elongata van } \\
\text { der Goot }\end{array}$ & $\begin{array}{l}\text { Kanyere (Bridelia } \\
\text { monoica) }\end{array}$ \\
\hline & & & Melanaphis sorghi (Theobald) & $\begin{array}{l}\text { Spodorolus (Spodorolus } \\
\text { sp.) }\end{array}$ \\
\hline & & & Myzus persicae (Sulzer) & $\begin{array}{l}\text { Cabai (Capsicum annum), } \\
\text { pepino (Solanum } \\
\text { muricatum) }\end{array}$ \\
\hline & & & $\begin{array}{l}\text { Rhodobium porosum( } \\
\text { Sanderson) }\end{array}$ & Mawar (Rossa sp.) \\
\hline & & & Rhopalosiphum maidis (Fitch) & Jagung (Zea mays) \\
\hline & & & Aphis (Toxoptera) aurantia & Kemuning (Murraya \\
\hline & & & Boyer de Fonscolombe & paniculata) \\
\hline & & & Aphis (Toxoptera) citricidus & Jeruk (Citrus spp.) \\
\hline & & & Uroleucon dubium (Holman) & $\begin{array}{l}\text { Lokatmala (Artemisia } \\
\text { vulgaris) }\end{array}$ \\
\hline
\end{tabular}


TABEL LANJUTAN

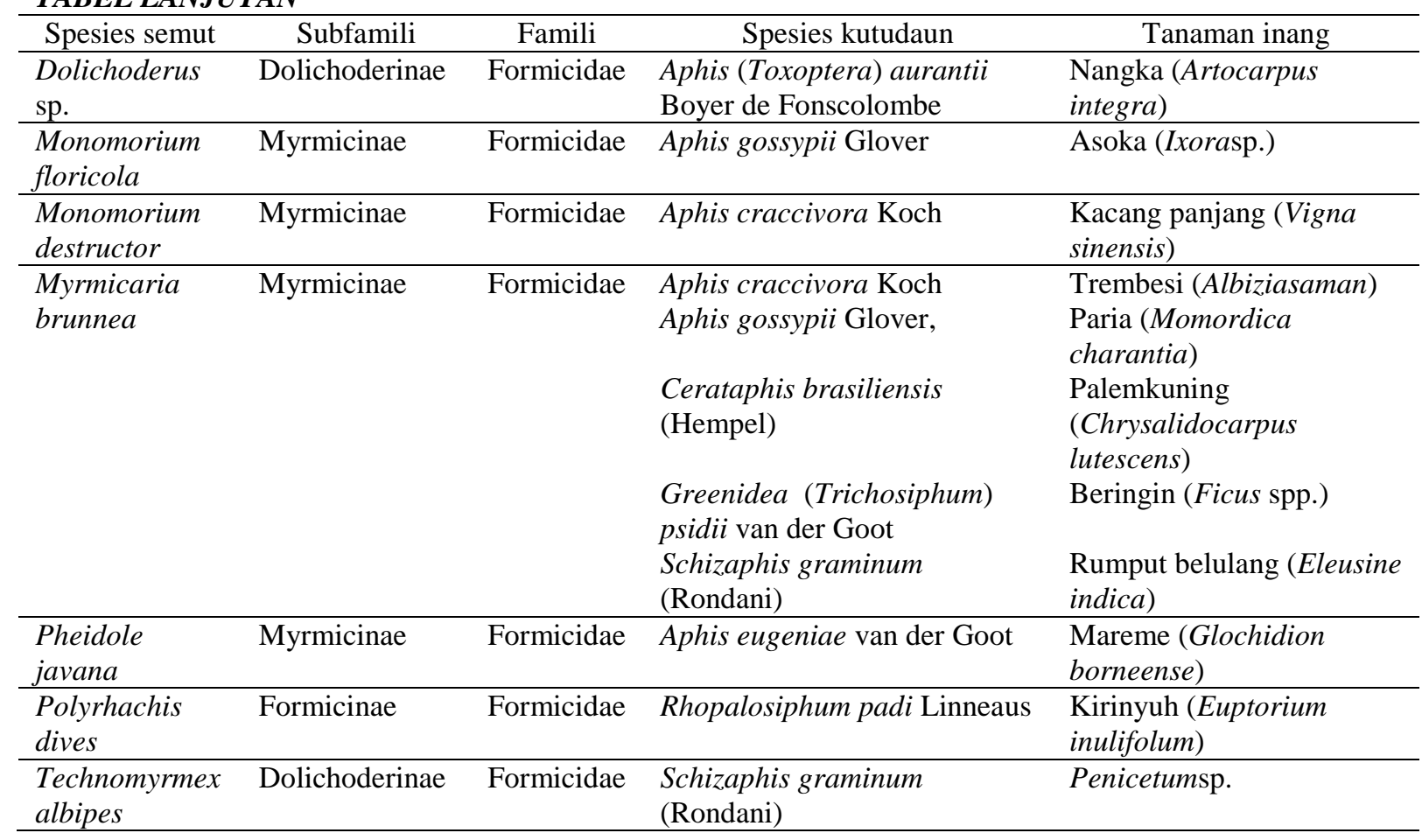

Banyak spesies semut bersimbiosis mutualisme dengan serangga kelompok Hemiptera dan $41 \%$ kelompok semut termasuk trophobioticspesies (Oliver et al., 2008). Myrmecophily banyak terjadi pada serangga kelompok Sternorrhyncha dan Auchenorrhyncha (Hemiptera), di antaranya kutudaun (Aphididae), kutu tempurung dan kutu-kutuan (Coccoidea), serta wereng batang (Membracidae) (Stadler \& Dixon, 2005). Kehadiran semut pada koloni Hemiptera dapat menyebabkan koloni Hemiptera menjadi lebih besar (Way 1963, Tegelaar, 2015) dan fekunditas yang lebih tinggi (Del-Claro \& Oliveira, 2000).

Semut hitam Dolichoderus thoracicus adalah spesies semut yang paling banyak ditemukan pada koloni kutudaun. Semut sering membentuk interaksi mutualisme dengan kutudaun. Pada interaksi yang terjadi, kutudaun akan mendapatkan perlindungan dari musuh alami (Buckley \& Gullan, 1991; Stadler \& Dixon, 2005; Way, 1963). Manfaat lain yang didapatkan oleh kutudaun adalah meningkatkan kuantitas dan kualitas embun madu yang dihasilkan kutudaun (Bach, 1991) serta berkurangnya kompetisi dengan serangga herbivora lainnya (Smith et al., 2008). Namun, dalam keadaan tertentu semut akan memangsa kutudaun (Oliver et al., 2012). Walaupun demikian keberadaan semut selalu dibutuhkan kutudaun. Ketiadaan semut predator pada koloni akan mengurangi reproduksi kutudaun tersebut (Stadler \& Dixon, 1998).

Tidak semua spesies semut yang bersifat melindungi kutudaun dari musuh alaminya. Nielsen et al. (2010) menyatakan bahwa hanya semut kasta pekerja dari spesies Formica podzolica yang selalu berperan menjaga kutudaun dan koloninya dari serangan musuh alami, sedangkan spesies semut lainnya dapat bersifat predator terhadap kutudaun. Keberadaan semut berkolerasi positif dengan kepadatan populasi dan fase kutudaun pada koloni kutudaun. Menurut Fischer et al. (2002), jumlah semut yang ditemukan pada koloni kutudaun yang memiliki imago lebih banyak daripada koloni yang banyak memiliki nimfa. Kehadiran semut berkorelasi dengan jumlah embun madu yang dihasilkan kutudaun (Fischer et al., 2002; Styrsky \& Eubanks, 2007). Way (1963) menyatakan bahwa semut membutuhkan nutrisi yang terdiri dari karbohidrat, asam amino dan air yang berada dalam embun madu yang dihasilkan kutudaun. Oleh karena itu, informasi dasar tentang jenis semut dan serangga parasitoid yang berasosiasi dengan kutudaun serta hubungan multi tropik level berimplikasi atau dapat dimanfaatkan dalam pengembangan strategi pengendaian hama terpadu kutudaun.

\section{KESIMPULAN DAN SARAN}

Parasitoid yang ditemukan pada koloni kutudaun di Jawa Barat ada empat spesies. Keempat spesies itu ialah Aphidius matricariae, Adialythus ambiguus, Praon absinthii (Braconidae), dan Psyllaephagus pilossus (Encyrtidae). Keempat spesies parasitoid tersebut merupakan parasitoid primer dan endoparasitoid pada kutudaun. Spesies parasitoid yang dominan ditemukan ialah $A$. matricariae. Spesies A. matricariae merupakan parasitoid kutudaun yang dikenal memiliki kemampuan memarasitisasi dan daya jelajah yang tinggi. Kemampuan parasitoid memarasitisasi dipengaruhi 
oleh keberadaan serangga lain pada koloni kutudaun. Keberadaan parasitoid ditemui pada ketinggian diatas $200 \mathrm{~m}$ dpl.

Spesies semut yang ditemukan berasosiasi dengan koloni kutudaun di beberapa tanaman inang dan berbagai daerah di Jawa Barat ada delapan spesies yang tergolong dalam famili Formicidae. Delapan spesies itu ialah, Dolichoderus thoracicus, Dolichoderus sp., Monomorium floricola, Monomorium destructor, Myrmicaria brunnea, Pheidole javana, Polyrhachis dives, dan Technomyrmex albipes. Spesies yang sering ditemukan ialah semut hitam (D. thoracicus). Belum ditemukan kespesifikan jenis semut dengan koloni spesies kutudaun. Namun, keberadaan parasitoid dan semut tersebut berimplikasi pada pengembangan strategi pengendalian kutudaun.

\section{DAFTAR PUSTAKA}

Acheampong S, Gillespie DR, \& Quiring DJ. 2012. Survey of parasitoids and hyperparasitoids (Hymenoptera) of the green peach aphid, Myzus persicae and the foxglove aphid, Aulacorthum solani (Hemiptera: Aphididae) in British Columbia. J Entomol Soc Brit Columbia. 109:12-22.

Akhtar MS, Dey D, \& Usmani MK. 2011a. A catalogue of aphid parasitoids (Hymenoptera: Braconidae: Aphidiinae) from India. Insecta Mundi. 151: 1-31.

Akhtar MS, Rafi U, Usmani MK, \& Dey D. 2011b. A review of aphid parasitoids (Hymenoptera: Braconidae) of Uttar Pradesh and Uttarakhand, India. Bio and Medicine. 3(2):320-323.

Bach CE. 1991. Direct and indirect interactions between ants (Pheidole megacephala), scales (Coccus viridis) and plants (Pluchea indica). Oecologia. 87:233-239.

Buckley RC, \& Gullan P. 1991. More aggressive ant species (Hymenoptera: Formicidae) provide better protection for soft scales and mealybugs (Homoptera: Coccidae, Pseudococcidae). Biotropica. 23:282-286.

Chaouche ST, \& Laamari M. 2015. Aphid parasitoid species (Hymenoptera: Braconidae: Aphidiinae) and their associations in biskra province, Algeria. J of Entomol and Zool Stud. 3(2):179-184.

DeBach P. 1974. Biological Control by Natural Enemies. Cambridge University Press. 323.

Del-Claro K, \& Oliveira PS. 2000. Conditional outcomes in a neotropical treehopper-ant association: temporal and species-specific variation in ant protection and homoptera fecundity. J Oecologia. 124:156-165.

Dey D, Akhtar MS. 2007. Diversity of natural enemies of Aphids belonging to Aphidiinae (Hymenoptera: Braconidae) in India. J Asia Pasific Entomol. 10(4):281-296.
Fisher RC, Richter A, Wanek W, \& Mayer V. 2002. Plants feed ants: food bodies of myrmecophytic Piper and their significance for the interaction with Pheidole bicornis ants. Oecologia. 133: 186-192.

Gontijo LM, Beers LH, \& Snyder WE. 2015. Complementary suppression of aphids by predators and parasitoids. J Biocontrol. 90:83-91.

Goulet H, \& Huber JT. 1993. Hymenoptera of The World: An Identification Guide to Families. Ontario (CN). Centre for Land and Biological Resources Research.

Hagen KS \& van den Bosch R. 1968. Impact of pathogens, parasites, and predators on aphids. Annu Rev Entomol. 13:325-384.

Hashimoto Y. 2003. Inventory and Collection: Total Protocol for Understanding of Biodiversity. Identification Guide to The Ant Genera of Borneo. Pp. 89-162 in Hashimoto Y, Rahman H. (eds.) 2003. Kinabalu: Research and Education Component, BBEC Programme (Universiti Malaysia Sebah), 310 pp.

Irsan C. 2004. Tumbuhan inang, parasitoid dan hiperparasitoid kutudaun Myzus persicae (Sulzer) (Homoptera: Aphididae) di sekitar Bogor dan Cianjur, Jawa Barat [disertasi]. Bogor (ID): Institut Pertanian Bogor.

Karuppaiah V, \& Sujayanad GK. 2012. Impact of climate change on population dynamics of insect pests. World J of Agr Sci.8(3):240246.

Kitt JT, \& Keller MA. 1998. Host selection by Aphidius rosae Haliday (Hymenoptera: Braconidae) with respect to assessment of host specificity in biological control. J Appl Entomol. 122: 57-690 p.

Kos K, Tomonovic Z, Petrovic-Obradovic O, Laznik Z, Vidrih M, \&Trand S. 2008. Aphids (Aphididae) and their parasitoids in selected vegetable ecosystems in Slovenia. Acta Agriculturae Slovenica. 15-22.

Manickavasagam S, \& Rameshkumar A. 2012. New distributional records of Encyrtidae (Hymenoptera: Chalcidoidea) from Puducherry, India. J Check List. 8(6):13371343.

Nielsen C, Agrawal AA, \& Hajek AE. 2010. Ants defend aphids against lethal disease. Biol Lett. 6: 205-208.

Noyes JS. 2004. Encyrtidae of Costa Rica (Hymenoptera: Chalcidodea), Metaphycus and related genera, parasitoids of scale insects (Coccoidea) and whiteflies (Aleyrodidae). Memoirs of the American Entomol Inst.73: 1-459.

Oliver TH, Leather SR, \& Cook JM. 2012. Ant larval demand reduces aphid colony growth rates in an ant-aphid interaction. Insect. 3:120-130. 
[Outrop] Orangutan Tropical Peatland Project. 2014. A Guide to the Ants of Sabangau. Oxford (UK): Department of Social Sciences,Oxford Brookes University.

Powell W, Pennacchio F, Poppy GM, \& Tremblay E. 1998. Strategies involved in the location of hosts by the aphid parasitoid Aphidius ervi Haliday (Hymenoptera: Braconidae: Aphidiidae). Biol Control. 11:104-112.

Rakhshani E, Talebi AA, Stary P, Tomanovic Z, \& Manzari S. 2007. Aphid-parasitoid (Hymenoptera, Braconidae, Aphidiinae) associations on willows and poplars in Iran. Acta Zool Acade Scien Hungaricae. 53(3):281-292.

Rakhshani E, Tomanovic Z, Stary P, Talebi AA, Kavallieratos NG, Zamani AA, \& Stamenkovic S. 2008. Distribution and diversity of wheat aphid parasitoids (Hymenoptera:Braconidae: Aphidiinae) in Iran. Eur. J. Entomol. 105: 863-870.

Rehman A, \& Powell W. 2010. Host selection behaviour of aphid parasitoids (Aphidiidae: Hymenoptera). J of Plant Breeding and Crop Sci. 2(10):299-311.

Roubinet E, Straub C, Jonsson T, Staudacher K, Traugott M, Ekbom B, \& Jonsson M. 2015. Additive effects of predator diversity on pest control caused by few interactions among predator species. Ecol Entomol. 40:362-371.

Schoonhoven LM, Jermy T, \& van Loon JJA. 2005. Insect Plant Biology from Physiology to Evolution. New York: Chapman \& Hall.

Shaw MR, \& Huddleston T. 1991. Classification and Biology of Braconid Wasps (Hymenoptera: Braconidae). Dolling WR, Askew RR (eds.). Handbooks for the Identification of British Insects. Volume 7, Bagian 11. London (GB): Royal Entomological Society of London.
Smith AA, \& Haight KL. 2008. Army ants as research and collection tools. J of Insect Sci. 8(71):15.

Stadler B, \& Dixon AFG. 2005. Ecology and evolution of aphid-ant interactions. Ann Rev of Ecol, Evol and Systematics. 36:345-72.

Starý P, \& Havelka J. 2008. Fauna and associations of aphid parasitoids in an updated farmland area (Czech Republic). Bull of Insect. 61:251276.

Starý P, Rakhshani E, Žikić V, Kavallieratos NG, Lavandero B, \& Tomanović Z. 2014. Altitudinal Zonation of Aphid Parasitoids (Hymenoptera: Braconidae: Aphidiinae) in the Neotropical Region. Entomol News. 124(2):86-97.

Styrsky JD, \& Eubanks MD. 2007. Ecological consequences of interactions between ants and honeydew-producing insects. Proc R Soc B. 274:151-164.

Tegelaar K. 2015. Dynamics of The Aphid-Ant Mutualism [dissertation]. Stockholm (SD): Department of Zoology, Stockholm University.

Volkl W, \& Stechmann DH. 1998. Parasitism of the black bean aphid (Aphis fabae) by Lysiphlebus fabarum (Hymenoptera: Aphidiidae): the influence of host plant and habitat. J Appl Entomol. 122: 201-206.

Way MJ. 1963. Mutualism between ants and honeydew producing Homoptera. Ann Rev of Entomol. 8:307-44.

WestrumK, Klingen I, Hofsvan GT, \& Hagvar EB. 2010. Checklist of primary parasitoid and hyperparasitoid (Hymenoptera, Apocrita) on aphids (Hemiptera, Aphididae) from Norway. Norwegian J Entomol.57:142-153.

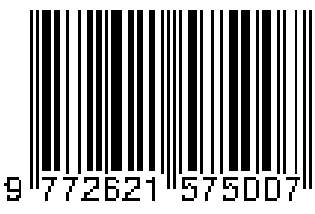

